Online Submission. Retrieved from http://eric.ed.gov/?id=ED542099. 2013.

[8]. Hounsell, D. Contrasting conceptions of essay-writing. The experience of learning, 1997. 2, 106-125.

[9].Andrews, R. The End of the Essay? Teaching in Higher Education. 2003. 8(1): 117-28.

[10].Womack, P. What are essays for? English in Education, 1993. 27.2, pp. 42-59

[11]. Winter, R. Alternative to the essay. The Guardian. Retrieved from http://www.theguardian.com/education/2003/jun/10/hi ghereducation.uk. 2003.

[12]. Tuckman, B. The Essay Test: A Look at the Advantages and Disadvantages. NASSP Bulletin, 1993. 77(555), 20-26.

[13]. Bachman, L. \& Palmer, A. Language testing in practice. Oxford: Oxford University Press. 1996.

[14]. Fulcher, G. Assessment in English for academic purposes: putting content validity in its place. Applied Linguistics, 1999. 20(2), 221-236.
[15]. Leedham, M. From traditional essay to 'Ready Steady Cook' presentation: Reasons for innovative changes in assignments. Active Learning in Higher Education, 2009. 10 (3), 191-206.

[16]. Weir, C. J. Understanding and developing language tests, New York: Prentice Hall. 1993.

[17]. Gibbs, G. Down with essays! The New Academic Spring. 1992.1(2), pp.18-19.

[18]. Badley, G. Valuing essays: essaying values. Research in Post-Compulsory Education, 2010. 15(1), 103-115.

[19]. Lee, Y. The process-oriented ESL writing assessment: Promises and challenges. Journal of Second Language Writing, 2006. 15(4), 307-330.

[20]. Hamp-Lyons, L. and Condon, W. Questioning Assumptions about Portfolio-Based Assessment. College Composition and Communication, 1993. 44 (2) pp.176-190.

[21].Fulcher, G. Practical language testing. London: Hodder Education. 2010.

[22]. Clarke, S. Outstanding Formative Assessment. London: Hodder Education. 2014.

UDK 378.046.4

GRNTI 14.37.29

\title{
PHILOSOPHICAL AND METHODOLOGICAL PROBLEMS OF PERSONALISED EDUCATION OF ADULTS IN TERMS OF POSTMODERN PLURALISM
}

\author{
Bulankina Nadezda Efimovna \\ Doctor, Philosophical \& Pedagogy Sciences, professor, \\ Novosibirsk Institute of In-Service Training and Retraining Teachers, \\ Novosibirsk, Russia
}

УДК 378.046 .4

ГРНТИ 14.37.29

\section{ФИЛОСОФСКИЕ И МЕТОДОЛОГИЧЕСКИЕ ПРОБЛЕМЫ ПЕРСОНИФИЦИРОВАННОГО ОБУЧЕНИЯ ВЗРОСЛЫХС ПОЗИЦИЙ ПОСТМОДЕРНИСТСКОГО ПЛЮРАЛИЗМА}

\author{
Буланкина Надежда Ефимовна \\ Доктор философских и педагогических наук, профессор, \\ заведуюшая кафедрой иноязычного образования, \\ Новосибирский институт повыления квалификациии \\ и переподготовки работников образования, \\ Новосибирск, Россия
}

\begin{abstract}
This research is devoted to the study of the methodology of personalized adult education in the value context of the historical and cultural epoch of Russia and the world as a whole, presented in the scientific and pedagogical discourse reflecting the pluralistic specifics of post-industrial society. The purpose of this study is to determine the specifics of personalized training and additional professional programs "Linguistics and Intercultural Interaction" in the formal education system being limited with temporal and economic framework designed to prepare graduates to meet the new professional activities of an educator. The problem field of this research is related to the theoretical and practical justification of the use of the methodology of language and cultural pluralism, as well as the pluralism of goals, objectives and content of adult education, focused on innovation and leadership development, on creative approaches to thinking, especially in school, where resources are limited, and subject to constant changes. The objectives of the research are threefold: a) to develop the principles of program development, b) the corpus of personalized humanitarian practices for organizing the event learning spaces of creative interaction of the participants, and c) to facilitate the stages of implementation of updated programs, and methodological content of training, as well as organizational difficulties associated with the formation of new professional competencies of the graduates of the programs in a new socio-cultural transforming space. In conclusion, the main results of the study at different stages of implementation of personalized learning technology
\end{abstract}


are formulated, and the prospects for using them in the format of remote learning and elearning are outlined for self-organized professional development.

\section{АННОТАЦИЯ}

Исследование посвящено изучению методологии персонифицированного обучения взрослых в ценностном контексте историко-культурной эпохи России и мира в целом, представленной в научнопедагогическом дискурсе и отражающей плюралистическую особенность постиндустриального общества. Цель работы состоит в определении особенностей персонифицированного обучения слушателей дополнительных профессиональных программ «Лингвистика и межкультурная коммуникация» в системе формального образования, которое будучи ограниченным временными и экономическими рамками призвано подготовить выпускников программ к выполнению новой профессиональной деятельности педагога. Проблемное поле исследования связано с теоретическим и практическим обоснованием использования методологии языкового и культурного плюрализма, а также плюрализма целей, задач и содержания обучения взрослых, ориентированных на инновации и лидерство в образовании, на использование творческих подходов к мышлению, особенно в пространстве школы, где ресурсы ограниченны, одновременно подвержены постоянным изменениям. В качестве задач исследования выступают принципы разработки программ и корпуса персонифицированных гуманитарных практик, составляющих развивающее событийное пространство творческого взаимодействия участников; этапы реализации обновленного программно-методического контента обучения, а также определение трудностей организационного характера, связанных с формированием новых профессиональных компетенций выпускников программ по искомому направлению в социокультурном трансформирующемся пространстве. В заключении сформулированы основные результаты исследования на разных этапах внедрения технологии персонифицированного обучения, намечены перспективы использования разработанных дополнительных программ профессиональной подготовки и переподготовки в формате удаленного обучения (elearning \& remote learning).

Keywords: postmodernism, deconstruction of education, elearning technology, personalized adult education, language and cultural pluralism, cultural self-determination, polilingual educational environment.

Ключевые слова: постмодернизм, деконструкция образования, технология электронного обучения, персонифицированное обучение, языковой и культурный плюрализм, культурное самоопределение, полиязыковое пространство.

Introduction. Several initiatives have been launched in our country with the aim of modernizing public services for providing new opportunities to adult citizens and social organizations. In this sense different reports and documents have indicated the need for investing in technologies to offer better educational services to the target audience composed of professionals, researchers and practitioners working in the field of teaching, training and talent development, to better understand the instructional environment under development and course implementation support (Subject Concepts; Federal State Education Standards, 2012; National project "Education", 2019; United Nations, 2012; ), and thus reduce the burden for them [1, p. 40]. These documents point out, first and foremost, interpretation and implementation of these main directions of development of the society and personal development in the educational space, in particular. This trend is named recurrent education, continuing personalized education or life-long education of adults via novel Pedagogy, Open Space Technology (elearning and remote learning, social media, etc), and Content Knowledge $[2 ; 3 ; 4 ; 5 ; 6]$ that has been promoted by important Russian organizations as Ministry of Instruction, and Institutions of In-Service and Upgrading of educational workers in terms of their professional skills and competences including a segment on motivating others $[1 ; 7]$.

As is the case, a leadership and innovation module is a must to be undertaken by advanced practitioners. Post-modern education needs updating objectives, and providing culturally oriented humanitarian practices to develop both professionals, and main conditions for culture self-determination of students who are able to use critical thinking to understand social situation, dominant national values in life, and other people's viewpoints as a value; to choose professional career for self-realization and self-improvement as a value, etc.

The appeal to these philosophical and methodological aspects of the problem from the viewpoints of new philosophy of education in terms of post-modernizm ideas (globalization, information space, macro-paradigm, rhizome-like learning, deconstruction of classical education, pluralism of activities, concepts, etc) is associated with the purpose of this research to clarify and adjust the author's comprehension model of the personal development in the system of life-long adult education into the context of new challenges of human existence in the world of modernity.

Scientific exposition includes methodology and materials of the research under critical analysis of modern scholarship and documents of planning educational processes in the system of professional training and retraining of educators in terms of axiological, communicative and activities approaches as the most valid in the evaluation of the results. First and foremost, the integration of novel approaches and processes in public education involves deconstruction, crucial changes not only in the use of technologies, but also in the culture of people (citizens, business, public workers, etc.), influencing the collaboration between citizens and public administration, as well as the collaboration between several public structures and administrators, ministries, educators, heads of educational institutions, etc. That is why scientific 
expozition of the study needs reflecting the results of the critical analysis of scientific literature, and also the proposals for the methodological frameworks of educational activities in the system of continuing education of pedagogues [3;7]. Secondly, the background of this problem lies in a branch of pedagogy named andragogy that has recently resurfaced as a learning approach after a decade of limited attention. As is the case, for many years and generations of students and educators, we were witnesses of Formal Education (FE) oriented on providing face-to-face practices every single day in the conditions of the knowledge-centered paradigm, according to which the process of knowledge was presented in a ready-made, well-organized information, and the socio-cultural component was minimum [4;7]. Thirdly, the transition to the polycultural paradigm in the early the Third Millenium means the transformation of the educational process into the interaction of the participants as equal partners, communicators, with the emphasis on the importance of the students' personal development, the growth of interest in the introduction to national culture identity, the development of his creative potential, social activity, and moral education (M.M. Bakhtin, G.N.Filonov, E. V. Bondarevskaya, V.V.Serikov, N.K.Borytko, 2000, etc), culture selfdetermination (E.A.Aleksandrova, N.E. Bulankina, V.Y.Kartashova, etc). These ideas have become the foundation as a significant part of the humanitarian space in the society[4] .

In the transforming social world the adult development education also needs deconstruction and renovation in terms of guiding distance education practice, and the ways in which distance educators develop, and deliver instruction using newer pedagogy, technology such as social media, and basic content knowledge. With appearance of the possibility of social elearning and remote or distant learning and teaching, adults become more autonomous, self-determined, and highly motivated. As is the case, the emphasis is replaced on personal development of learner capacity and capability with the aim of producing learners who are highly motivated and well-prepared for the complexities of today's workplace $[3 ; 5 ; 6]$. This methodological approach often becomes of prior importance for designing optional educational programs to realize such a paradigm of education that is radically changed, and is characterized with pluralism of ideas, ways of life, language and culture pluralism, concepts and approaches to innovative educational processes, strategic planning and measures of its elimination $[1 ; 2 ; 4 ; 5]$.

In the light of these tendencies culture and education have become the basic factors of the development of modern civilization and cooperation of all social systems. The process of forming universal values, world and national culture values, and multicultural education is becoming the area of interaction between education and culture as the relationship between traditions and innovations that concern the ways and means of transmitting these dominant values from generation to generation. Cultural and educational institutions with traditionally established systems carry out the process of transferring knowledge, experience and elements of human culture.

However, only in recent years, these innovative processes are increasing and changing, that culture and national dominant values are becoming the core of the objectives, content, forms and methods of training and retraining of adults. They strengthen the impact on the organization of the educational process. These organizations and their practitioners are in search of helping students move from surface learning through a lecture approach and to gaining deeper learning through immersion in research activity to generate relevant motivation to a novel setting of life, workforce, and workplaces $[2 ; 3 ; 5 ; 6]$.

The socio-cultural environment formed by the work and efforts of different generations has a significant impact on the formation of a person's character, his style of behavior, aspirations, and their value component. Within this new educational paradigm, culture is considered as a prerequisite, the basis for choosing the content of education and its result. In modern conditions, the main task of education is not only the transfer of knowledge and experience, but also the development of human culture. In this regard, new generation of students is supposed to be interested in the culture of their own people and the culture of other countries, and along with the wellknown foundations for the development of education (financial and economic, legal, conceptual and methodological, professional and activity), the valuesemantic, determined by the type and level of culture of society, acquires special significance.

Therefore, it is emphasized that in the era of a total digital information environment (network communities, interest groups, etc.), entering the space of essentially polyphonic interaction of people, different cultures, different attitudes and life positions, different language traditions, in the process of "language self-determination" as an integral part of cultural self-determination of the individual is even more relevant to education itself as a cultural phenomenon, requiring special attention to the problems of humanitarian organization and selforganization via polylingual culture of citizens [5;7]. While the goal is the realization of the personality through various languages of education (verbal and non-verbal, natural and artificial, languages, academic subjects, language, personality, etc., man as a system of relations with the environment is an integral component of the process of mastering cultural values and ethical norms for the formation of moral and professional conduct in a harmonious civilized society $[2 ; 4]$. As a result, in the process of mastering cultural values, a person forms their qualities for their open manifestation in the society. The openness is a specific feature of a cultural, professional, and healthy civil society. Culture, being the most conservative in its manifestation, preserves the traditions and habits of generations. Only on these basis it is possible to develop novel human activity and educational values.

Results of the study devoted to comprehension model of teaching innovation through collaborative 
learning includes the most important conceptual provisions of educational paradigm and contemporary challenges, reflected in the works of domestic and foreign researchers, philosophers, teachers, psychologists and didactics, forming the methodological basis of the research highlight several important socially significant philosophical, theoretical and methodological aspects of the formation of the cultural-oriented personality in the modern information environment within an integrated model of cultural self-identity that must be reflected in planning optional educational programmes [3;7].

Framework One. Multilingual educational space as part of a multicultural social space defined as polyphonic environment languages, joining in the communication of the participants of the educational process in the search for personal meaning of acquired knowledge, and above all, meaning in the broad education of the individual (education/training/development). The educational process as humanitarian phenomenon is regarded as the cultural environment of polyphonic positive interaction at the level of the individual and universal cultures, and individual language concept sphere of the personality, to create a text of "language work" in search of ways and means of expression, in search of the place in the world. Institutional programs that have incorporated new approaches based on these examples and research results about the polylingual essence of the conceptosphere of the educational space, course design elements that are characteristic of culture selfdetermination are identified [3;4;].

Framework Two. The concept of the second. Cultural self-determination of an individual in a multilingual educational environment is considered as an integral personal value formation a) actualized in the information and educational environment of polylanguages and multicultures (the phenomenon of polylanguage information and educational environment as a value), b) manifested in the national consciousness in the conditions of social interaction and professional choice of the person who speaks the languages as expressive means of polyculture (the phenomenon of multilingual conceptual sphere of the individual as a value), and c) reflected in the readiness to use all the variety of expressive means of mastering and preserving national cultural values for understanding the meaning of human existence, self-realization in life (the phenomenon of humanitarian self-organization in the cultural environment as a value).

Framework Three. The development/formation of an event-based information environment for interaction between direct participants in the educational process involves systematic research (analysis, synthesis, classification and generalization) and the development of the entire complex of developing situations and developing tasks of an integrative nature over the subject content of education to maintain a high level of poly-linguistic conceptosphere of the modern person's personality, its thesaurus, intellectual component (language intelligence) and its social (language) status.

To wind down the concept of the comprehensive model of integration dominant values into recurrent education of adults [3;7] we formulate in brief some of the provisions obtained as a result of testing and further implementation of a comprehensive value model for the formation of a multilingual information and educational environment at the regional level.

The first area of current research is the need to overcome the lack of personal space of a teacher working in a modern multilingual information environment, in the aspect of providing time for alternative forms of education. According to our 2020 data, a small $(8 \%)$ percentage of teachers, working at the limit of their resource capabilities, engage in systematic self-education in their subject area in the space of pedagogical growth and skill: participate in various projects (national, regional and school), formalizing their results in the format of publications; organize author's workshops, seminars, open classes, network communities and interest groups, replicating the positive pedagogical experience and results of students $[3 ; 4]$. The second problem area is the need to reformat the system of professional education of teachers in the aspect of broad education, fundamental methodological preparation for solving urgent problems of education and development of young people. In this context, it is necessary to make the most of dominant values to integrate them into the educational process in terms of strengthening the humanitarian poly / language component, which is based on the language personality as a value, patriotism as a value, and self-education through life as a value. The third problem area is the importance of raising the status of teachers, their economic and temporary independence. The results of our experience in the system of continuous education, teacher professional space often has neither the time nor the financial resources to complete systemic work on improvement of its linguistic culture, and conceptual sphere in general, is limited to four walls, and is not always relevant and verified information when possible, to use e-learning, it was repeatedly stated and state scientists and educators-practitioners.

In conclusion there are several reasons for writing this article. First of all, this opus is a tribute to a prominent scientist, a University educator, the Founder of Rostov-Don Scientific School of Learner-Centered Learning and Teaching approach in Russian educational system, E. V. Bondarevskaya, who tirelessly and fruitfully worked in this sphere, and whose research works for many teachers is the source of wisdom, talent, content, practicality, and for me, the author of this text, a source of inspiration. Secondly, the importance of this issue for Russian school as a whole is in the fact that this fruitful approach lays grounds for the Russian Concept of spiritual and moral education of the youth. And finally, no one will dispute, hope so, the concept in brief that Evgenja Vasiljevna repeated everywhere - at conferences, in disputes, in her articles and discussions on the most crucial issues of modern education which concern destruction of the social infrastructure of the world of childhood; neglect of family education; criminalization of the environment of children and the youth; the decline of school and University education, its detachment from the real life 
problems of children and students; dissociation of education and culture, professional training. And as a result, there is a noticeable decrease in the overall level of culture and moral education of children and the youth, manifested in lack of spirituality, extreme rationalism of thinking, loss of moral guidelines, and in the spread of antisocial behaviors in the youth environment, adolescent maladaptation, and offenses.

Fully joining this concept, the author of this article is sure of the idea that spiritual and moral education of the individual is possible in an environment that motivates and cultivates a growing person [4] to the current realities of modernity with a positive connotation - kindness, spirituality in the highest sense of the word, tact, responsiveness, etc. The list goes on indefinitely. There are many words in the Russian language that characterize these highly moral concepts. However, such concepts are less and less common in our vocabulary for fruitful and positive communication and multicultural interaction at different levels of the social life. Moreover, in today's society there are several other realities along with positive ones. They often function in the school environment, one of these realities, the uncertainty of the cultural and educational ideal, and also Neglect of Affairs in the sphere of practical education exacerbated the crisis as pedagogical theory. And, unfortunately, the above realities continue to prevail and dominate in our difficult world, which is covered by Chaos and Crisis in many areas of human life, including schools, universities, and in the family.

\section{References}

1. Moukhlaeva T. (2003). Adult Education in Russia // Crossing borders and forming networks. Costs and benefits for adult education. Educational work and Research Unit of the Association of Austrian Adult Education Centres, Vienna. Pp. 44-45. In Engl.

2. Khukhlaev, O., Gritsenko, V. , Pavlova, O., Tkachenko, N., Usubian, S., \& Shorohkova, V. (2020). Comprehensive model of intercultural competence: theoretical substantiation // RUDN Journal of Psychology and Pedagogics. No. 17 (1): 13-28. In Engl. 3. Lopatukhina, T., Bulankina, N., Mishutina, O., \& Asten, T. (2020). Foreign language professionally oriented training students of technical universities in the system of recurrent and life-long education (in Engl.)

https://iated.org/concrete3/paper_detail.php?paper_id= 80519 The 14th annual International Technology, Education and Development Conference, INTED 2020, Proceedings, Valencia (Spain) on the 2nd, 3rd and 4th of March, 2020. pp.7413-7419. In Engl.

4. Bulankina N., Umbrashko, K., Li Nan and Sun Yumen. (2019). Axiological component of professional readiness of a modern teacher to work in the aspect of the cross-border region. SHS Web of Conferences Volume 70 (2019). EDP Sciences Trends in the Development of Psycho-Pedagogical Education in the Conditions of Transitional Society (ICTDPP2019), Rostov-on-Don, Russia, November 22-23, 2019. I.V. Abakumova, and E.V. Vorobyova (Eds.). Published online Section \#2: Cross-border education in the modern world. https://doi.org/10.1051/shsconf/20197002002/https:// www.shs-

confereNCES.org/articles/shsconf/abs/2019/11/conten ts/contents.html// in Engl.

5. Tomalin, B., Stempleski, S. Cultural Awareness / B. Tomalin, S. Stempleski. - Oxford University Press, OUP, 1994. - 160p. in Engl.

6. Cerny, M. The way to open education through the modern technology // Procedia - Social and Behavioral Sciences. 2015. Vol. 174. Pp.3194-3198.

7. Lopatukhina, N. Bulankina, O. Mishutina, T. Asten. English Language Education theory: frameworks, text-centered technique, paradimes/paradigms (in Engl.).

https://iated.org/concrete3/paper_detail.php?pape r_id=80521 73p. P.57 The 14th annual International Technology, Education and Development Conference, INTED2020, Proceedings, Valencia (Spain) on the 2nd, 3rd and 4th of March, 2020. pp.7420-7423.

\section{РОЛЬ СУЩНОСТНЫХ ОСОБЕННОСТЕЙ СЕМЬИ КАК САМАЯ ВАЖНАЯ РОЛЬ ОБЩЕСТВА В НАЧАЛЕ ТРЕТЬЕГО ТЫСЯЧЕЛЕТИЯ}

Колесов В.И.

Заслуженный работник высшей школь Российской Федерации, профессор, доктор педагогических наук, кандидат экономических наук, профессор Лужского института (филиала)ЛГУ им. А.С. Пушкина

\section{THE ESSENTIAL FEATURES OF A FAMILY AS A BASIS OF THE SOCIETY IN THE THIRD MILLENNIUM}

V.I. Kolesov

honored scholar of higher education of russian federation, full professor, doctor of pedagogical sciences, candidate of economic sciences, professor at the department of pedagogics, psychology and theory of translation of saint petersburg university of management technologies and economics 